\title{
KANDUNGAN PROTEIN KASAR DAN SERAT KASAR TONGKOL JAGUNG FERMENTASI MENGGUNAKAN CAIRAN RUMEN SEBAGAI INOKULAN
}

(Contains of rude protein and rude corn cobs fermentation using rumen fluid as inoculant)

\author{
Farliansyah $^{1{ }^{*}}$, J. Mustabi ${ }^{2)}$, S. Syahrir ${ }^{2)}$, \\ ${ }^{1)}$ Mahasiswa Program Strata Satu Fakultas Peternakan, Universitas Hasanuddin. \\ ${ }^{2)}$ Fakultas Peternakan, Universitas Hasanuddin. \\ *Email :Fharly.kmkm98@gmail.com
}

\begin{abstract}
Corn cobs contain high crude fiber and low protein value. Fermentation technology using rumen fluid as an inoculant is expected to improve the nutritional quality of corn cobs. This study aims to determine the effect of giving cow's rumen fluid as inoculants to the value of crude protein and crude fiber of corn cobs. This study was designed based on a Completely Randomized Design (CRD) with 3 treatments with 4 replications. Treatment P0: corncob fermentation without addition of rumen liquid (Control), P1: Corncob $+15 \%$ Rumen Fluid, P3: Corncob $+30 \%$ Rumen Fluid. Result of variace analysis showed that the fermentation of corncobs using rumen fluid as an inoculant had no significant effect $(\mathrm{P}>0.05)$ on the crude protein of corncobs and had significantly effect $(\mathrm{P}<0.01)$ on the crude fiber of corncobs. The results showed the average crude protein content of treatment P0: 2.78\%, P1: $3.11 \%$ and $\mathrm{P} 2: 3.08 \%$, the average crude fiber content of treatment P0: $36.55 \%, \mathrm{P} 1: 37.82 \%$ and P2: $40.51 \%$, Conclusion, the addition of $15 \%$ rumen fluid inoculant (P1) is better than other treatments, has the highest crude protein content and is able to increase the crude protein content of $0.33 \%$ from the control treatment (P0). The higher addition of rumen liquid inoculant increases fermented corncob coarse fiber content.
\end{abstract}

Keywords : Rumen Fluid, Corn Cobs, Crude Protein, Crude Fiber and Fermentation

\begin{abstract}
ABSTRAK
Tongkol jagung mengandung serat kasar yang tinggi dan nilai protein yang rendah. Teknologi fermentasi dengan menggunakan cairan rumen sebagai inokulan diharapkan mampu meningkatkan kualitas tongkol jagung.Penelitian ini bertujuan untuk mengetahui pengaruh pemberian cairan rumen sapi sebagai inokulan terhadap nilai protein kasar dan serat kasar tongkol jagung.Penelitian ini dirancang menggunakan Rancangan Acak Lengkap (RAL) dengan 3 perlakuan dengan 4ulangan. Perlakuan P0 : fermentasi tongkol jagung tanpa penambahan cairan rumen
\end{abstract}


Farliansyah, J. Mustabi , S. Syahrir / Buletin Nutrisi dan Makanan Ternak 14 (2) : 28-40

(Kontrol), P1 : Tongkol Jagung + Cairan Rumen 15\%, P3 : Tongkol Jagung + Cairan Rumen $30 \%$. Hasil analisis ragam menujukkan bahwa fermentasi tongkol jagung dengan menggunakan cairan rumen sapi sebagai inokulan tidak memberikan pengaruh yang nyata $(\mathrm{P}>0.05)$ terhadap kandungan protein kasar tongkol jagung tetapi memberikan pengaruh yang sangat nyata $(\mathrm{P}<0.01)$ terhadap kandunga serat kasar tongkol jagung. Hasil penelitian memperlihatkan rataan kandungan protein kasar perlakuan P0 : 2.78\%, P1 : 3.11\% dan P2 :3.08\%, rataan kandungan serat kasar perlakuan P0 : 36.55\%, P1 : 37.82\% dan P2 : 40.51\%. Kesimpulan, penambahan inokulan cairan rumen $15 \%$ (P1) lebih baik daripada perlakuan lainnya, memiliki kandungan protein kasar tertinggi dan mampu meningktakan kandungan protein kasar $0.33 \%$ dari perlakuan kontrol (P0). Semakin tinggi penambahan inokulan cairan rumen semakin meningkatkan kandungan serat kasar tongkol jagung fermentasi.

Kata kunci: Cairan Rumen, Tongkol Jagung, Protein Kasar, Serat Kasar dan Fermentasi

\section{PENDAHULUAN}

Jagung merupakan salah satu produk pertanian yang banyak dihasilkan di Sulawesi Selatan. Menurut data Badan Pusat Statistik Provinsi Sulawesi Selatan (2015) produksi tanaman jagung pada tahun 2015 mencapai 1.528.413 ton. Tanaman jagung terdiri dari 20\% tongkol yang merupakan limbah dari tanaman jagung (Retnani dkk., 2009) jika dikonversikan dengan jumlah produksi jagung pada tahun 2015 maka daerah Sulawesi Selatan berpotensi menghasilkan tongkol jagung sebanyak 305.682,6 ton. Jumlah limbah tersebut dapat dikatakan sangat banyak dan akan menjadi sangat potensial jika dapat dimanfaatkan.

Tongkol jagung adalah limbah yang diperoleh ketika biji jagung dirontokkan dari buahnya sehingga diperoleh jagung pipilan sebagai produk utamanya dan sisa buah yang disebut tongkol (Islamiyati dkk., 2017). Tongkol jagung sangat potensial untuk dapat dimanfaatkan sebagai pakan alternatif ruminansia, namun kenyataannya saat ini pemanfaatannya belum optimal sebagai bahan pakan. Hal ini disebabkan karena tongkol jagung mengandung serat yang tinggi $(46,52 \%)$ dan nilai protein yang rendah (2,67\%) (Suryani dkk., 2016).

Limbah pertanian sebagai pakan alternatif memiliki berbagai faktor penghambat sehingga diperlukan upaya pengolahan melalui sentuhan teknologi pengolahan pakan. Penerapan teknologi dalam pemanfaatan limbah pertanian sebagai 
Farliansyah, J. Mustabi , S. Syahrir / Buletin Nutrisi dan Makanan Ternak 14 (2) : 28-40

pakan diupayakan dalam meningkatkan kualitas dari bahan pakan tersebut, misalnya kemampuan daya simpan, tingkat kecernaan dari bahan pakan, eliminasi anti nutrisi dan peningkatan kandungan nutrisi pakan (Ariyanto dan Slamet., 2014).

Teknologi yang dapat diterapkan dalam pengolahan tongkol jagung sebagai pakan alternatif yaitu dengan melalui teknologi fermentasi.Menurut Wina (2005) tujuan fermentasi adalah memanfaatkan kerja mikroorganisme untuk merombak bahan-bahan yang bersifat serat kasar menjadi bahan-bahan yang mudah dicerna seperti karbohidrat dan protein. Mikroorganisme yang dimanfaatkan dapat berbentuk probiotik (bakteri, jamur, khamir atau campurannya) atau dapat berupa produk fermentasi atau produk ekstrak dari suatu proses fermentasi.

Rekayasa bioteknologi fermentasi dengan menggunakan mikroba yang berasal dari cairan rumen sapi diharapkan dapat melonggarkan ikatan kompleks lignoselulosa dan ligno-hemiselulosa serta meningkatkan protein pada limbah pertanian. Menurut Hernawati et al., (2010) untuk meningkatkan nilai nutrisi limbah pertanian, salah satu caranya adalah pemanfaatan proses biologis menggunakan bakteri selulotik. Perlakuan biologis menggunakan inokulan bakteri selulolitik berperan meningkatkan kualitas limbah pertanian sebagai pakan, maka dari itu perlu dilakukan penelitian penggunaan cairan rumen sebagai inokulan dalam memfermentasi tongkol jagung.

Tongkol jagung sangat potensial untuk dapat dimanfaatkan sebagai pakan alternatif ruminansia, namun kenyataannya saat ini pemanfaatannya belum optimal sebagai bahan pakan, hal ini disebabkan karena tongkol jagung mengandung serat kasar yang tinggi dan nilai protein yang rendah, maka dari itu perlu dilakukan pengolahan untuk meningkatkan nilai nutrisinya, salah satu cara untuk meningkatkan nilai nutrisi tongkol jagung yaitu dengan teknologi fermentasi menggunakan cairan rumen sapi. Fermentasi merupakan metode pemanfaatan mikroba untuk mengubah bahan baku menjadi produk yang bernilai lebih tinggi. Cairan rumen memiliki berbagai mikroorganisme yang dapat membantu dalam meningkatkan nilai nutrisi yang diharapkan dapat menjadi inokulan dalam proses fermentasi tongkol jagung. 
Farliansyah, J. Mustabi , S. Syahrir / Buletin Nutrisi dan Makanan Ternak 14 (2) : 28-40

Tujuan penelitian ini yaitu untuk mengetahui pengaruh pemberian cairan rumen sapi sebagi inokulan terhadap nilai protein kasar dan serat kasar tongkol jagung. Kegunaan penelitian ini yaitu diharapkan menjadi bahan informasi kepada masyarakat tentang pemanfaatan cairan rumen sapi sebagai inokulan pada fermentasi dalam meningkatkan kualitas tongkol jagung.

\section{METODE PENELITIAN}

\section{Waktu dan Tempat Penelitian}

Penelitian ini dilakasanakan pada bulan Maret 2020 sampai dengan April 2020. Penelitian ini terdiri dari dua tahap, tahap pertama pembuatan fermentasi tongkol jagung di laboratorium Valorisasidan tahap kedua analisa tongkol jagung hasil fermentasi di laboratorium Kimia Pakan Fakultas Peternakan Universitas Hasanuddin Makassar.

\section{Materi Penelitian}

Bahan yang akan digunakan pada penelitian ini yaitu tongkol jagung (PK 2.56\% dan SK 37,44\%), dedak padi (PK 5.60\% dan SK 1.96), cairan rumen, kantong plastik, dan bahan-bahan yang digunakan pada analisis protein kasar dan serat kasar.

Peralatan yang digunakan pada penelitian ini yaitu timbangan, termos air, gelas ukur, sarung tangan karet, kasa steril, kain mitela, vakum dan alat-alat yang digunakan pada analisis protein kasar dan serat kasar.

\section{Metode Pelaksanaan a.Rancangan penelitian}

Penelitian ini dilakukan dengan metode Rancangan Acak Lengkap (RAL) (Gasperz.1991) yang terdiri dari 3 perlakuan dan 4 ulangan, perlakuan yang di berikan sebagai berikut :

$$
\begin{aligned}
& \mathrm{P} 0=\text { Tongkol Jagung tanpa penambahan cairan rumen (Kontrol) } \\
& \mathrm{P} 1=\text { Tongkol Jagung + Cairan Rumen } 15 \% \\
& \mathrm{P} 2=\text { Tongkol Jagung + Cairan Rumen } 30 \%
\end{aligned}
$$

\section{b. Prosedur penelitian}

1. Pengambilan cairan rumen, sapi yang baru dipotong dipisahkan bagian rumennya, kemudian isi yang ada dalam rumen sapi dikeluarkan khususnya pada bagian rumen. 
Farliansyah, J. Mustabi , S. Syahrir / Buletin Nutrisi dan Makanan Ternak 14 (2) : 28-40

Cairan rumen yang digunakan yaitu cairan rumen yang memiliki warna kehijauan yang menandakan bahwa sapi tersebut mengkonsumsi pakan hiajauan, isi rumen tersebut diperas menggunakan kain kasa berlapis untuk diambil cairan rumennya dan disimpan didalam termos yang sebelumnya telah diisi dengan air hangat bersuhu $40^{\circ} \mathrm{C}$ agar suhu termos sesuai dengan suhu cairan rumen, air di dalam termos dikeluarkan terlebih dahulu sebelum dimasukkan cairan rumen. Cairan rumen siap digunakan sebagai inokulan fermentasi.

2. Tongkol jagung yang telah di giling menggunakan hummer mill (Mesin Penghancur/pencacah) ditimbang masing-masing sebanyak 950 gram setiap unit percobaan

3. Tongkol jagung di campur rata dengan dedak padi sebanyak 5\% di setiap sampel setelah itu memasukkan kedalam kantong plastik dan selanjutnya di campur dengan cairan rumen sapi sebanyak $15 \%$ dan $30 \%$. Kemudian sampel di ikat dan di vakum untuk mengeluarkan udara (Anaerob)

4. Fermentasi dilakukan selama 21 Hari

5. Setelah proses fermentasi selesai, diambil sampel sebanyak 100 gram, kemudian dioven selama 3 hari dengan suhu $50^{\circ} \mathrm{C}$ (sampai beratnya konstan). Tongkol jagung kemudian diblender hingga halus dengan ukuran 20 mesh. Tongkol jagung siap digunakan untuk analisis protein kasar dan serat kasar menggunakan metode AOAC (2012).

Parameter yang di amati yaitu uji kandungan Protein kasar dan Serat kasar menurut AOAC (2012).

\section{Uji Protein (\%)}

Tahap pertama adalah menimbang kurang lebih 0,5 gr sampel kemudian masukkan kedalam labu khjedhal $100 \mathrm{ml}$. Menambahkan kurang lebih 1 gr campuran selenium dan $10-25 \mathrm{ml} \mathrm{H}_{2} \mathrm{SO}_{4}$ pekat.Destruksi didalam lemari asam sampai jernih.Setelah dingin, dituang kedalam labu ukur $100 \mathrm{ml}$ dan dibilas dengan air suling.Masukkan $5 \mathrm{ml}$ sampel menggunakan pipet kedalam labu khjedhal dan tambahkan 5 ml larutan $\mathrm{NaOH}$ 30\% dan air suling 100 ml.Siapkan labu penampung yang terdiri dari $10 \mathrm{ml} \mathrm{H}_{3} \mathrm{BO}_{3} 2 \%$ ditambah dengan 4 tetes larutan indicator 
campuran dalam Erlenmeyer $100 \mathrm{ml}$.Suling hingga volume penampung menjadi \pm 50 ml.Bilas ujung penyuling dengan air suling kemudian penampung dan isinya di titrasi dengan larutan $\mathrm{HCL}$ atau $\mathrm{H}_{2} \mathrm{SO}_{4}$. Model matematika penentuan kadar protein kasar yaitu sebagai berikut.

$$
\text { Kadar Protein Kasar }=\left(\frac{\mathrm{V} \times \mathrm{N} \times 14 \times 6,25 \times \mathrm{P}}{\text { Berat Sampel }(\mathrm{mg})}\right) \times 100 \%
$$

Keterangan:

$\mathrm{V}=$ Volume titrasi;

$\mathrm{N}=$ Normalitas larutan $\mathrm{HCl}$ atau $\mathrm{H}_{2} \mathrm{SO}_{4}$ sebagai penitar $(0,0103)$;

$\mathrm{P}=$ Faktor pengencer $(50 \mathrm{mg})$.

\section{Uji Serat Kasar}

Menimbang kurang lebih 0,5 gr sampel kemudian masukkan kedalam tabung reaksi. Menambahkan $30 \mathrm{~mL} \quad \mathrm{H}_{2} \mathrm{SO}_{4} 0,3 \mathrm{~N}$ dan direfluks selama 30 menit. Menambahkan $15 \mathrm{~mL} \mathrm{NaOH}$ 1,5 N kemudian direfluks selama 30 menit dan disaring menggunakan sintered glass no. 1 dan mengisap dengan pompa vakum. Setelah itu, mencuci dengan menggunakan $50 \mathrm{cc}$ air panas, $50 \mathrm{cc} \mathrm{H}_{2} \mathrm{SO}_{4} 0,3 \mathrm{~N}, 50 \mathrm{cc}$ air panas dan $50 \mathrm{cc}$ alkohol. Mengeringkan dalam oven pada suhu $105^{\circ} \mathrm{C}$ selama 8 jam atau dibiarkan selama semalam. Kemudian mendinginkan dengan didalam desikator selama 30 menit kemudian lakukan penimbangan (a gram). Setelah itu, tanur selama 3 jam lalu masukkan ke dalam desikator selama 30 menit kemudian lakukan penimbangan (b gram). Model matematika penentuan kadar serat kasar yaitu sebagai berikut.

$$
\text { Kadar Serat Kasar }=\left(\frac{a-b}{\text { Berat Sampel }} \times 100 \%\right) \times\left(\frac{100}{\text { BK Sampel }}\right)
$$

\section{c. Analisis Data}

Data yang diperoleh dianalisis statistik dengan menggunakan sidik ragam sesuai Rancangan Acak Lengkap (RAL) 3 perlakuan dengan 4 ulangan dengan model matematikanya adalah :

$$
\mathbf{Y}_{i j}=\mu+\pi_{i}+\epsilon_{i j}
$$


dengan :

$\mathrm{i}=1,2$ dan 3

$\mathrm{j} \quad=1,2,3$, dan 4

$\mathrm{Y}_{\mathrm{ij}} \quad=$ respon atau nilai pengamatan dari perlakuan ke-i dan ulangan ke-j.

$\mu \quad=$ rata-rata umum.

$\pi_{\mathrm{i}} \quad=$ pengaruh perlakuan ke-i.

$\epsilon_{\mathrm{ij}} \quad=$ pengaruh galat percobaan dari perlakuan ke-i dan ulangan ke-j.

Data yang di peroleh dianalisis menggunakan sidik ragam dengan bantuan software SPSS versi 16, jika berpengaruh nyata dilanjutkan dengan uji Duncan (Duncan's Multiple Random Tests = DMRT) (Gasperz 1991).

\section{HASIL DAN PEMBAHASAN}

\section{Kandungan Protein Kasar Tongkul Jagung Fermentasi Menggunakan Cairan Rumen sebagai Inokulan}

Protein merupakan salah satu zat makanan yang berperan dalam penentuan produktivitas ternak. Jumlah protein dalam pakan ditentukan dengan kandungan nitrogen bahan pakan melalui metode Kjeldahl yang kemudian dikali dengan faktor protein; 6.25,angka 6.25 diperoleh dengan asumsi bahwa protein mengandung $16 \%$ nitrogen (Suparjo, 2010). Hasil penelitian pengaruh penambahan cairan rumen dengan level 15\% dan 30\% terhadap kandungan protein kasar tongkol jagung fermentasi dapat dilihat pada Gambar 1.

Hasil analisis ragam menunjukkan bahwa fermentasi limbah tongkol jagung dengan menggunakan berbagai level cairan rumen tidak memberikan pengaruh yang nyata $(\mathrm{P}>0.05)$ terhadap kandungan protein kasar tongkol jagung. Meski tidak memberikan pengaruh yang nyata, telah terjadi peningkatan protein pada tongkol jagung yang difermentasi dengan menggunakan cairan rumen. Menurut Hernawati et al., (2010) Peningkatan kandungan protein kasar dalam proses fermentasi dengan menggunakan cairan rumen, disebabkan peningkatan aktivitas bakteri selulolitik dalam mengikat nitrogen sebagai bahan dasar untuk sintesis protein, peningkatan kadar nitrogen ini sangat menguntungkan bakteri selulolitik untuk melakukan 
pertumbuhan dan melakukan aktivitas secara optimal menyebabkan kadar protein meningkat dari bakteri selulolitik yang merupakan protein sel tunggal.

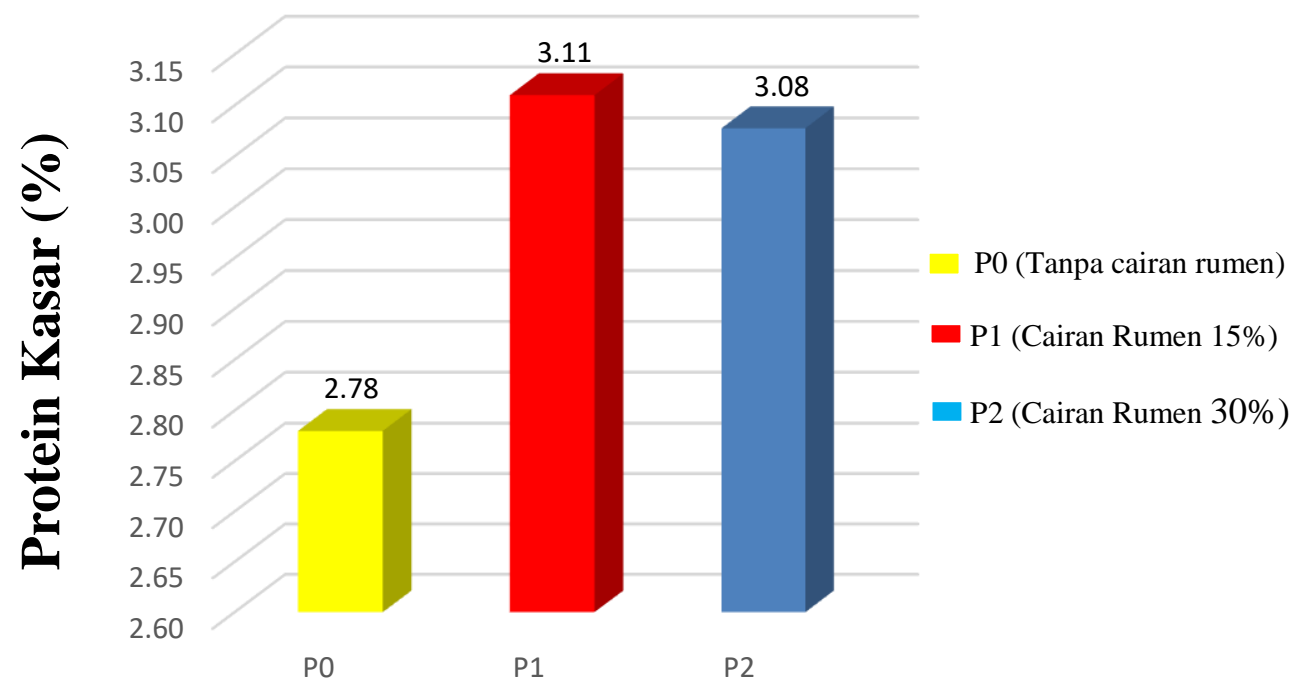

Gambar 1. Kandungan protein kasar tongkol jagung fermentasi

Gambar 1 menunjukkan adanya peningkatan nilai protein kasar pada perlakuan P1 dan P2. Tingkat kandungan protein kasar tertinggi di hasilkan oleh perlakuan P1 yaitu penambahan cairan rumen dengan level 15\%. Hal tersebut terjadi karena didalam proses fermentasi terdapat berbagai mikroba yang mampu mendegradasi bahan organik yang selanjutkan akan disintesis sehingga menghasilkan protein. Hal ini sesuai dengan pendapat Palupidkk., (2011) yang menyatakan bahwa pada proses fermentasi mikroba akan menghasilkan enzim yang akan mendegradasi senyawa-senyawa kompleks menjadi lebih sederhana, dan mikroba juga akan mensintesis protein.

Perlakuan P2 (Penambahan cairan rumen 30\%) menunjukkan kandungan protein kasar lebih rendah dari perlakuan P1 (penambahan cairan rumen 15\%).Hal tersebut menunjukkan bawa penambahan cairan rumen $30 \%$ mengakibatkan persentasi mikroba lebih tinggi dan tidak sebanding dengan kandungan nutrisi yang 
Farliansyah, J. Mustabi , S. Syahrir / Buletin Nutrisi dan Makanan Ternak 14 (2) : 28-40

dibutuhkan mikroba untuk hidup dan berkembang. Hal tersebut sesuai dengan pendapat Nalardkk., (2014)yang menyatakan bahwa persentase bakteri selulolitik yang tinggi dan tidak diimbangi dengan kandungan nutrisi yang sesuai dapat menyebabkan aktivitas bakteri selulolitik untuk tumbuh selama proses fermentasi akan menjadi terhambat. Tanpa kandungan nutrisi yang lengkap perombakan protein tidak dapat berjalan optimal karena bakteri selulolitik tidak akan hidup dan berkembang dengan baik.

Pada penelitian ini menujukkan adanya perubahan aroma pada tongkol jagung yang difermentasi menggunakan cairan rumen, aroma yang di hasilkan setelah penyimpanan beraroma agak asam berbeda sebelum dilakukan penyimpanan yang beraroma khas cairan rumen, perubahan aroma ini menunjukkan adanya proses fermentasi oleh adanya aktivitas mikroba yang menghasilkan aroma asam. Hal tersebut sesuai dengan pendapat Fitria dan Candrasari (2019) yang menyatakan bahwa aroma asam dapat menunjukan bahwa proses fermentasi telah menghasilkan asam laktat yang berasal dari bakteri asam laktat.Bakteri asam laktat mempunyai kemampuan mengubah berbagai senyawa yang terdapat pada media menjadi senyawa yang lebih sederhana, memberikan flavor dan aroma yang khas pada pakan (Riswandi et al., 2017).

\section{Kandungan Serat Kasar Tongkol Jagung Fermentasi Menggunakan Cairan Rumen sebagai Inokulan}

Serat kasar merupakan bagian dari karbohidrat dan didefinisikan sebagai fraksi yang tersisa setelah didigesti dengan larutan asam sulfat standar dan sodium hidroksida pada kondisi yang terkontrol.Serat kasar yang terdapat dalam pakan sebagian besar tidak dapat dicerna pada ternak non ruminansia namun digunakan secara luas pada ternak ruminansia, sebagian besar berasal dari sel dinding tananam dan mengandung selulosa, hemiselulosa dan lignin (Suparjo, 2010).Hasil penelitian pengaruh penambahan cairan rumen dengan level 15\% dan 30\% terhadap serat kasar tongkol jagung fermentasi dapat dilihat pada Gambar 2. 
Farliansyah, J. Mustabi , S. Syahrir / Buletin Nutrisi dan Makanan Ternak 14 (2) : 28-40

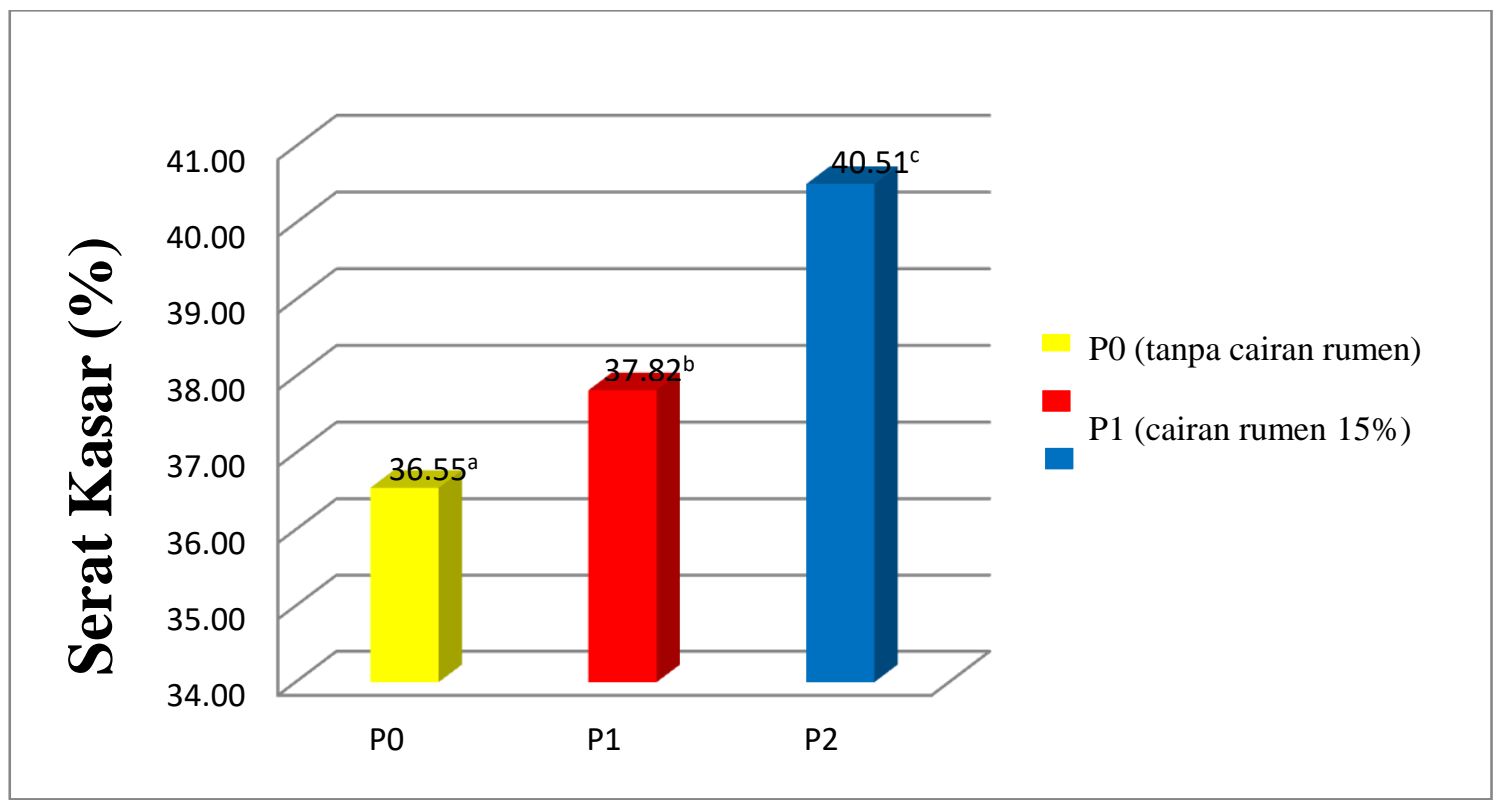

Keterangan : Superskrip yang berbeda menunjukkan perbedaan yang sangat nyata $(\mathrm{P}<0.01)$ Gambar 2. Kandungan Serat kasar tongkol jagung fermentasi

Hasil analisis ragam menunjukkan bahwa fermentasi limbah tongkol jagung dengan menggunakan berbagai level cairan rumen memberikan pengaruh yang sangat nyata $(\mathrm{P}<0.01)$ terhadap kandungan serat kasar tongkol jagung. Hasil Uji Jarak Berganda (Duncan), perlakuan P0 (Kontrol) P1 (Cairan Rumen 15\%) dan P2 (Cairan Rumen 30\%) menunjukkan adanya perbedaan kandungan serat kasar, semakin tinggi level pemberian cairan rumen kandungan serat kasar semakin meningkat. Hal ini berbeda dengan penelitian Widaningsi dkk., (2018) telah melakukan penelitian fermentasi tongkol jagung menggunakan cairan rumen dengan level pemberian $20 \%$, $40 \%$, 60\% dan $80 \%$, semakin tinggi level pemberian cairan rumen yang digunakan kandungan serat kasar tongkol jagung semakin menurun.

Pada Gambar 2 menujukkan penambahan cairan rumen 30\% (P2) meningkatkan serat kasar lebih tinggi dari pada penambahan cairan rumen $15 \%(\mathrm{P} 1)$. Peningkatan serat kasar dimungkinan terjadi akibat mikroba yang ada pada tongkol jagung fermentasi tidak mendegradasi serat, mikroba cenderung memanfaatkan nutrien lain untuk memenuhi kebutuhan nutrisinya. Hal tersebut sesuai dengan pendapat Santi (2018) yang menyatakan bahwa dalam proses fermentasi mikroba 
Farliansyah, J. Mustabi , S. Syahrir / Buletin Nutrisi dan Makanan Ternak 14 (2) : 28-40

cenderung memanfaatkan nutrisi yang mudah tercerna untuk pertumbuhannya salah satunya adalah BETN (Karbohidrat mudah terlarut), mikroba cenderung memanfaatkan BETN yang tersedia dibandingkan serat kasar yang sulit dicerna. Rohmawati, (2015), nilaiBETN tergantung pada nilai nutrisi seperti protein kasar, lemak kasar, abu dan serat kasar, semakin tinggi PK, LK, abu dan SK makanilai BETN semakin rendah. Penurunan kandungan BETN ini bisa terjadi karena dalam proses fermentasi akan terjadi proses degradasi bahan (substrat) oleh mikroba.Menurut Hastuti, dkk (2011) bahwa adanyapeningkatan aktivitas mikroba dalam mendegradasi substrat, maka akan mempengaruhi juga pemakaian energi (BETN) yang semakin banyak pula, sehingga dalam aktivitas mikroba yang tinggi dapat menurunkan kandungan BETN

Peningkatan serat kasar juga dimungkinkan terjadi akibat adanya kitin yang di duga ikut memberikan konstribusi terhadap peningktana serat kasar, kitin merupakan biopolimer alami kedua terbanyak setelah selulosa, merupakan komponen utama penyusun eksoskeleton Arthropoda dan dinding sel fungi (Kusumaningsih dkk, 2004). Kitin adalah senyawa yang stabil terhadap reaksi kimia, rendahnya reaktivitas kimia, tidak beracun (non toxic) dan bersifat biodegradable. Kitin tidak larut dalam air (bersifat hidrofobik), dalam alkohol serta tidak larut dalam asam maupun alkali encer (Pratiwi. 2014).

\section{KESIMPULAN}

Berdasarkan hasil dan pembahasan dapat disimpulkan bahwa penambahan cairan rumen sapi sebagai inokulan dalam fermentasi tongkol jagung tidak memberikan pengaruh yang nyata terhadap kandungan protein kasar, penambahan inokulan cairan rumen $15 \%$ (P1) lebih baik daripada perlakuan lainnya, memiliki kandungan protein kasar tertinggi dan mampu meningktakan kandungan protein kasar $0.33 \%$ dari perlakuan kontrol (P0). Semakin tinggi penambahan inokulan cairan rumen semakin meningkatkan kandungan serat kasar tongkol jagung fermentasi. 
Farliansyah, J. Mustabi , S. Syahrir / Buletin Nutrisi dan Makanan Ternak 14 (2) : 28-40

\section{DAFTAR PUSTAKA}

Ariyanto, S.E dan S. Slamet. 2014. Teknologi pengolahan limbah pertanian tongkol jagung untuk mengatasi masa paceklik pakan ternak. Dian Mas 3(2) : 129134.

Badan Pusat Statistik Sulawesi Selatan. 2015. Produksi tanaman jagung Sulawesi selatan. https://sulsel.bps.go.id/site/resultTab (diakses 26 Januari 2020).

Fitria, R., D. Puspita dan Candrasari. 2019. Kualitas fisik amoniasi fermentasi (amofer) janggel jagung dengan penambahan m21 dekomposer pada level yang berbeda. Bulletin of Applied Animal Research. 1(1) : 35-39.

Gasperz, 1991.Teknik Analisis dalam Penelitian Percobaan. Bandung : Tarsito.

Hastuti, D., S. N. B. Awami., dan M Iskandar. 2011. Pengaruh perlakuan teknologi amofer (amoniasi fermentasi) pada limbah tongkol jagung sebagai alternatif pakan berkualitas ternak ruminansia. Mediagro.7(1) : 55 - 65

Hernawati, T., M. Lamit., H. A. Hermadi dan S. H. Warsito. 2010. Bakteri selulotik untuk meningkatkan kualitas pakan komplit berbasis limbah pertanian. Veterinaria Medika. 3 (3) : 205-208

Kusumaningsih, T., A. Masykur dan U. Arief. 2004. Pembuatan kitosan dari kitin cangkang bekicot (achatina fulica). Biofarmasi. 2 (2) : 1693-2242.

Nalar, H. P., Herliani, B. Irawan., S. N. Rahmatullah., Askalani dan N. M. A. Kurniawan. 2014. Pemanfaatan Cairan Rumen Dalam Proses Fermentasi Sebagai Upaya Peningkatan Kualitas Nutrisi Dedak Padi Untuk Pakan Ternak. Prosiding Seminar Nasional "Inovasi Teknologi Pertanian Spesifik Lokasi”. Banjar Baru 6-7 agustus 2014.

Palupi, Rizky dan A. Imsya. 2011. Pemanfaatan Kapang Trichoderma Viridae Dalam Proses Fermentasi Untuk Meningkatkan Kualitas Dan Daya Cerna Protein Limbah Udang Sebagai Pakan Ternak Unggas. Seminar Nasional Teknologi Peternakan dan Veteriner 2011.Bogor . Hal 672-677.

Pratiwi, R. 2014. Manfaat kitin dan kitosan bagi kehidupan manusia.Oseana. 39(1):35-43

Retnani, Y., L. Hernawati., W. Widiarti dan E. Indahwati. 2009. Uji sifat fisik dan palatabilitas biskuit limbah tanaman jagung sebagai substitusi sumber serat untuk domba. Buletin Peternakan. 33(3): 162-169. 
Farliansyah, J. Mustabi , S. Syahrir / Buletin Nutrisi dan Makanan Ternak 14 (2) : 28-40

Riswandi, S. Sandi dan I.P. Sari.2017. Amoniasi Fermentasi (Amofer) Serat Sawit denga Penambahan Urea dan Effectie Microorganism-4 (EM-4) terhadap Kualitas Fisik, Derajat Keasaman (pH), Bahan Kering dan Bahan Organik.Prosiding Seminar Nasional Lahan Suboptimal 2017.Palembang, 1920 Oktober 2017.

Santi. 2018. Kadar protein kasar dan serat kasar jagung kuning giling pada difermentasi dengan em-4 pada level yang berbeda. Jurnal Ilmu Pertanian Universitas Al Asyariah. 3(2) : 84-86.

Suparjo. 2010. Analisis Bahan Pakan Secara Kimiawi: Analisis Proksimat dan Analisis Serat. Fakultas PeternakanJambi :Universitas Jambi.

Wina, E. 2005. Teknologi pemanfaatan mikroorganisme dalam pakan untuk meningkatkan produktivitas ternak ruminasia di Indonesia : sebuah review. Wartazoa, 15 (4) : 173-186. 